\title{
Spontaneous adrenal hemorrhage during pregnancy: review of literature and case report of successful conservative management
}

\section{Gebelik sirasında spontan adrenal kanama: Literatürün gözden geçirilmesi ve başarll bir konservatif tedavi olgu raporu}

Mohammad Saleem Wani ${ }^{1}$, Zahoor Ahmed Naikoo', Munfat Ahmed Malik², Arif Hamid Bhat ${ }^{1}$, Muneer Ahmed Wani', Syed Arshid Qadri ${ }^{2}$

${ }^{\prime}$ Department of Urology, Sher-i-Kashmir Institute of Medical Sciences, Soura Srinagar, Kashmir, J and K, India

${ }^{2}$ Department of General Surgery, Sher-i-Kashmir Institute of Medical Sciences, Soura Srinagar, Kashmir, J and K, India

\section{Abstract}

Spontaneous adrenal hemorrhage is an acute hemorrhage from the adrenal gland which occurs in the absence of trauma. The incidence of this condition during pregnancy is unknown. We describe a patient with massive unilateral adrenal hemorrhage which occurred during labor. The patient was successfully managed conservatively with complete resolution of the hematoma. A review of the literature of this rare condition is also presented.

(J Turkish-German Gynecol Assoc 2011; 12: 263-5)

Key words: Adrenal hemorrhage, post partum, retroperitoneal bleed

Received: 5 September, 2010

Accepted: 20 October, 2010

\section{Özet}

Spontan adrenal kanama, adrenal bezden travma olmaksızın oluşan akut kanamadır. Bu durumun gebelik sırasındaki insidansı bilinmemektedir. Biz doğum sırasında ortaya çıkan ağır tek taraflı adrenal kanamalı bir hasta olgusunu tarif ediyoruz. Hasta başarılı bir şekilde konservatif olarak tedavi edildi ve hematom tamamen ortadan kalktı. Ayrıca bu ender durumun literatür derlemesi de sunulmaktadır.

(J Turkish-German Gynecol Assoc 2011; 12: 263-5)

Anahtar kelimeler: Adrenal kanama, doğum sonrası, retroperitoneal kanama

Geliş Tarihi: 05 Eylül 2010

Kabul Tarihi: 20 Ekim 2010

\section{Introduction}

Adrenal hemorrhage during delivery is a rare cause of massive retroperitoneal hematoma and must be differentiated from hemorrhage caused by trauma, primary adrenal or metastatic tumors (1). The main symptoms are hemorrhagic shock, flank pain and fever in some cases. Adrenal hemorrhage has been reported in $0.3 \%-1.8 \%$ of undetected cases in autopsy studies, although extensive bilateral adrenal hemorrhage may be present in $15 \%$ of individuals who die of shock (2). Unilateral adrenal hemorrhage most frequently is caused by blunt abdominal trauma (traumatic adrenal rupture), but it also has occurred in liver transplant recipients and patients with primary adrenal or metastatic tumors (3). Unilateral adrenal hemorrhage is infrequently associated with otherwise uncomplicated pregnancy, neurofibromatosis, or long term non steroidal anti-inflammatory drug use (4). During pregnancy, idiopathic spontaneous, unilateral adrenal hemorrhage has been reported rarely (5).

We present a case of idiopathic spontaneous unilateral massive adrenal hemorrhage occurring during labor, which was managed conservatively.

\section{Case Report}

A 35 year-old female in the ninth month of a twin pregnancy with complaints of pregnancy induced hypertension was admitted for delivery. On examination the patient was hypertensive and had pitting edema in the lower limbs and puffiness of her face. Ultrasonography showed a live twin pregnancy of 38 weeks with one cephalic and one breech presentation, adequate liquor and a fundal placenta. Haemogram and serum chemistry of the patient were within normal limits.

The patient was induced and delivered of live twins. The placenta was removed spontaneously and completely. The patient developed atonic post partum hemorrhage (PPH), which was managed conservatively with Inj. Syntocinon $20 \mathrm{IU}$ in 5\% dextrose and Inj. Prostadin (PGF2a) and Tab Misoprostol (PGE1) 400 mcg per vaginum. Twelve hours after the delivery, the patient developed breathlessness and a dry cough. Her pulse rate was 126 beats/ min and BP 90/60 mmHg, the chest. X-ray and ECG were normal. The patient was resuscitated with $\mathrm{O} 2$ inhalation, blood transfusion and inotropic support with Inj. Dopamine $5 \mathrm{mcg} / \mathrm{min}$. She developed severe pain in 
her right flank and ultrasonography revealed a right peri-renal hematoma. Contrast CT scan of the abdomen revealed an extensive abdomino-pelvic retroperitoneal hematoma extending from the dome of the diaphragm to the pelvis (Figure 1,2). The patient's vital signs stabilized on intra-venous fluids, antibiotics and blood transfusion. The retroperitoneal hematoma self- tamponaded and did not require surgical management. Upon conservative therapy, the clinical condition improved and parameters of inflammation normalized. Contrast CT carried out after 4 weeks revealed a resolving retroperitoneal hematoma with a thick walled adrenal cyst around the adrenal gland. There was no evidence of a hormone producing adrenal tumor, adrenal insufficiency caused by adrenal hemorrhage or a coagulopathy. A contrast CT 8 weeks later revealed a thick walled adrenal cyst with complete resolution of the retroperitoneal hematoma (Figure 3).

\section{Discussion}

Adrenal hemorrhage is a relatively uncommon condition with a variable and non- specific presentation that may lead to acute adrenal crisis, shock and death unless it is recognized promptly and treated appropriately. Several risk factors have been associated with it based on case reports.

Although the precise mechanisms leading to adrenal hemorrhage are unclear; in non-traumatic cases available evidence has implicated Adreno-Corticotropic Hormone (ACTH), adrenal vein spasm and thrombosis and normally limited venous drainage of adrenal in the pathogenesis of the condition (2). Unilateral adrenal hemorrhage occurs in $2 \%$ of patients with penetrating trauma (1), whereas right adrenal hemorrhage is reported in $2 \%$ of liver transplant patients. Hemorrhagic tumor infarction due to primary or metastatic tumors can cause unilateral adrenal hemorrhage $(3,6)$. Isolated case reports in association with long term non-steroidal anti-inflammatory drug use in uncomplicated pregnancy and neurofibromatosis have been reported. Idiopathic unilateral adrenal hemorrhage is a rare

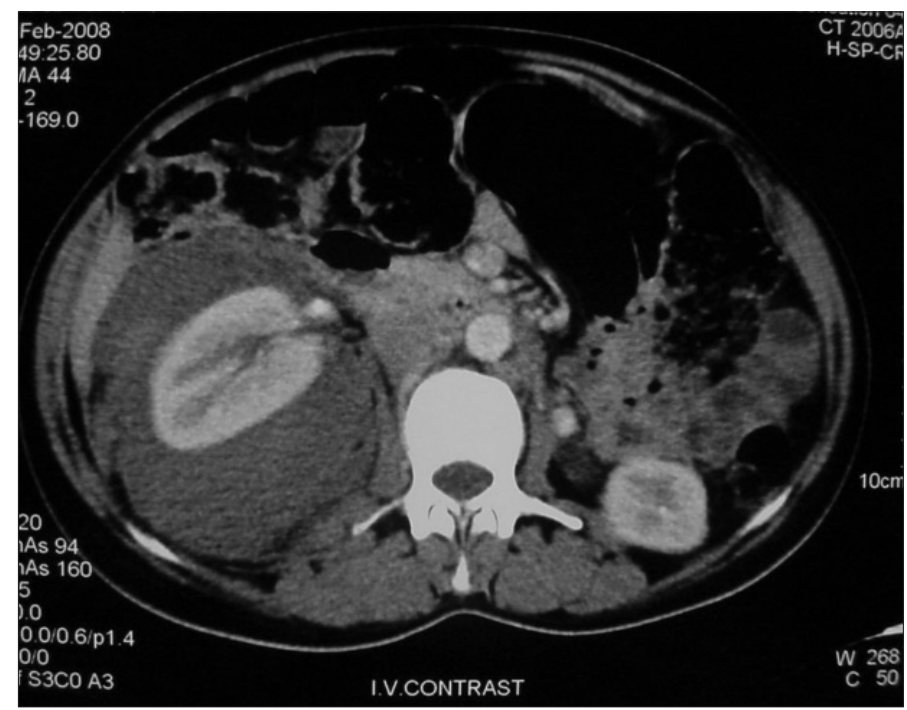

Figure 1. Contrast Enhanced Computerized Tomogram of abdomen at time of admission entity that may either have an acute presentation, such as massive retroperitoneal bleeding or an adrenal mass (2).

The main symptoms of the condition are hemorrhagic shock, flank pain and fever. Signs of acute abdomen including guarding, rigidity or rebound tenderness have been reported in 15\%$20 \%$ because of the retroperitoneal location of adrenals (2). Obstetric causes of bilateral adrenal hemorrhage include

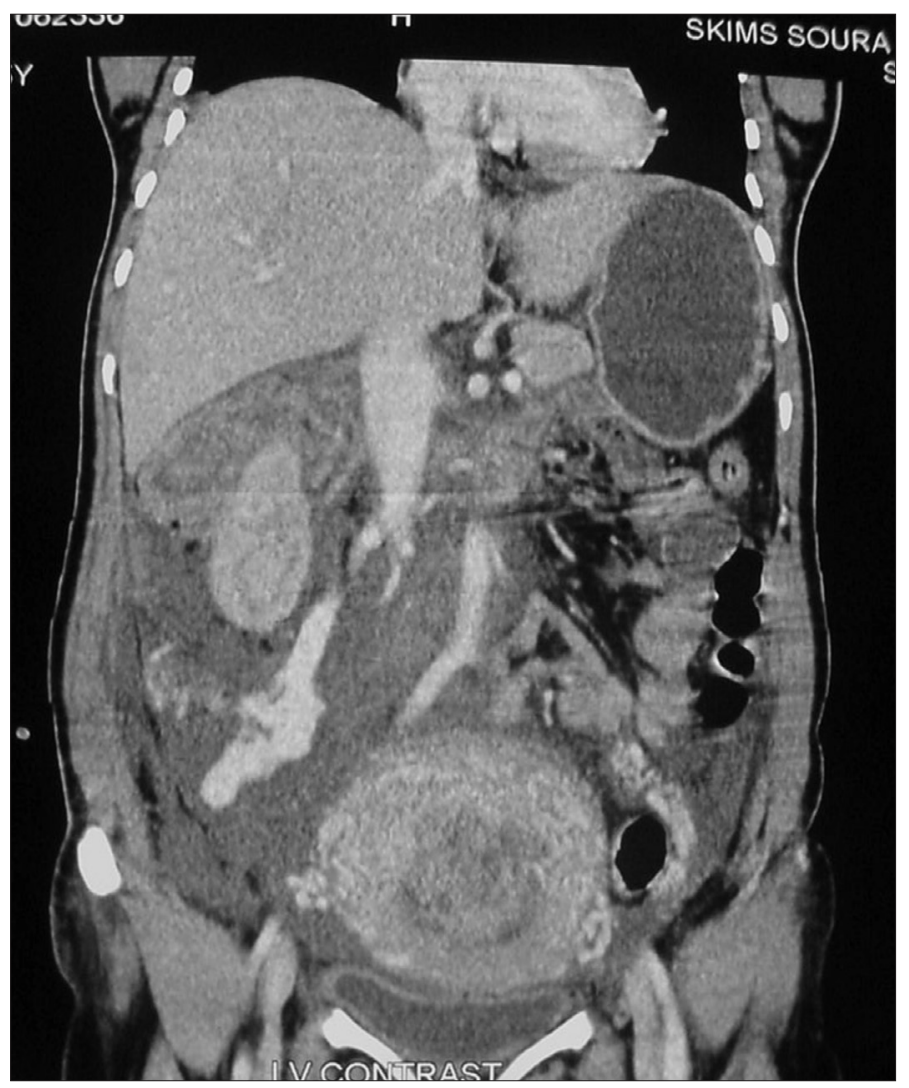

Figure 2. Reconstructed coronal view showing the extent of hematoma

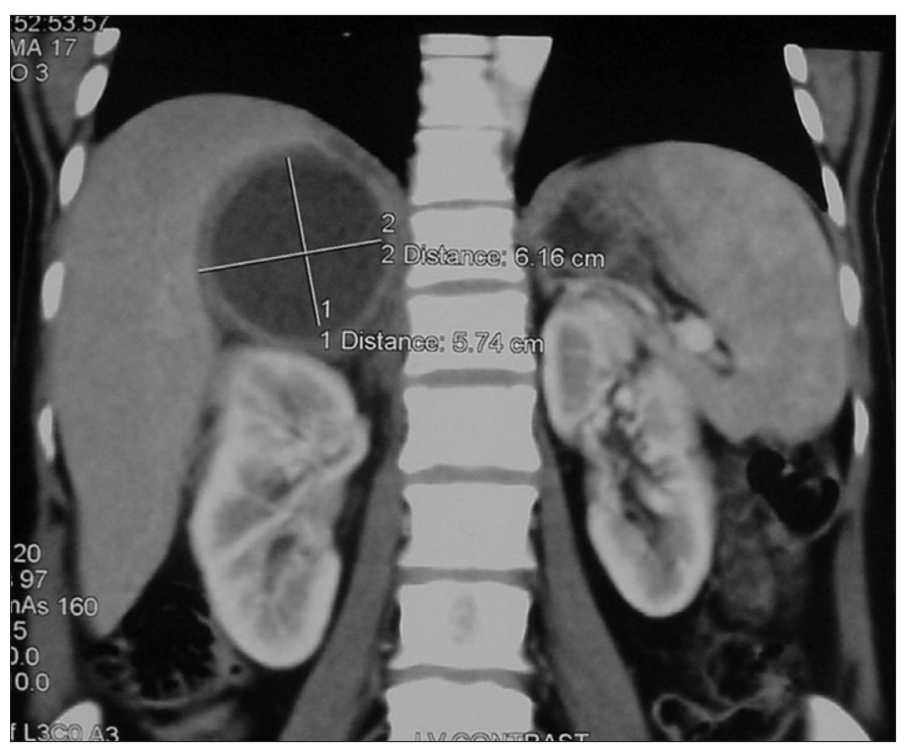

Figure 3. Adrenal Cyst on follow up scan 
toxemia of pregnancy, spontaneous abortion, postpartum hemorrhage, twisted ovarian cyst in pregnancy and, more recently described, antiphospholipid antibody syndrome (7). Spontaneous adrenal hemorrhage during pregnancy has rarely been described. The present case also had pregnancy induced hypertension.

Ultrasonography examination of the adrenals, including Doppler study, provides useful information regarding hemorrhage into the adrenal gland. Several weeks after the acute event, as the hematoma becomes cystic, the central echogenicity associated with adrenal hemorrhage decreases.

Contrast CT scan of the adrenals is the study of choice in demonstrating the adrenal hemorrhage. The findings suggestive of hemorrhage into the adrenal are adrenal echogenicity with contrast enhancement, streaky appearance of peri-renal fat, perinephric hematoma, and retroperitoneal hematoma in a massive bleed. Several weeks after the acute hemorrhage, the CT scan shows a gradual decrease in size and attenuation. In addition, the adrenal may have a cystic appearance as was seen with the present case. Spontaneous adrenal hemorrhage may occur in pregnancy in the absence of trauma or sepsis. Thus, adrenal hemorrhage should be considered in the differential diagnosis of abdominal or flank pain with retroperitoneal hematoma in patients after delivery.

\section{Conclusion}

Spontaneous adrenal hemorrhage during pregnancy is a rare condition. The diagnosis is confirmed by MRI and CT scan.
Adrenal hemorrhage should be considered in the differential diagnosis of a massive retroperitoneal hematoma in pregnant women after delivery.

\section{Conflict of interest}

No conflict of interest was declared by the authors.

\section{References}

1. Gavrilova-Jordan L, Edmister WB, Farrell MA, Watson WJ. Spontaneous adrenal hemorrhage during pregnancy: a Review of literature and case report of successful conservative management. Obstet Gynecol Surv March 2005; 60: 191-5. [CrossRef]

2. Kovacs KA, Lam YM, Pater JL. Bilateral massive adrenal hemorrhage. Assessment of putative risk factors by case controlled method. Medicine (Baltimore) 2001; 80: 45-53. [CrossRef]

3. Hiroi N, Yanagisawa R, Yoshida-Hiroi M, Endo T, Kawase T, Tsuchida Y, et al. Retroperitoneal hemorrhage due to bilateral adrenal metastasis from lung adenocarcinoma. J Endocrinol Invest 2006; 29: 551-4.

4. Merkle W. Spontaneous adrenal gland hemorrhage in adults. Urologe A 1986; 25: 343-6.

5. Kazarians B, Kausch I, Gellissen J, Doehn C, Jocham D. Spontaneous hemorrhage of adrenal gland during pregnancy. Aktuelle Urol 2007; 38: 403-5. [CrossRef]

6. Shah HR, Love LL, Williamson MR, Buckner BC, Feriss EJ. Hemorrhagic adrenal metastasis: CT findings. J Comput Assist Tomogr 1989; 13: 77-81. [CrossRef]

7. Espinosa G, Santos E, Cervera R, Piette JC, de la Red G, Gil V, et al. Adrenal involvement in antiphospholipid syndrome: clinical and immunological characteristic of 86 patients. Medicine (Baltimore) 2003; 82: 106-18. [CrossRef] 